\title{
Movement of individual humpback whales between wintering grounds of Oceania (South Pacific), 1999 to 2004
}

\author{
Claire Garrigue ${ }^{1}$, Rochelle Constantine ${ }^{2}$, Michael Poole $^{3}$, Nan Hauser ${ }^{4}$, Phil Clapham ${ }^{5}$, Michael Donoghue, \\ Kirsty Russell 2 , Dave Paton ${ }^{7,8}$, Dave K. Mattila ${ }^{9}$, Jooke Robbins ${ }^{10}$ And C. Scott BakeR ${ }^{2,11}$ \\ Contacte-mail: op.cetaces@lagoon.nc
}

\begin{abstract}
The movement of individual humpback whales between regional breeding grounds of Oceania (South Pacific) was documented by individual identification photographs collected from 1999 to 2004. Photographs were collected with comparable effort across the six years in four primary island breeding grounds: New Caledonia, Tonga (Vava'u) the Cook Islands and French Polynesia (Mo'orea and Rurutu); with smaller effort in adjacent regions: Vanuatu, Fiji, Samoa, Niue and American Samoa. Interchange among wintering grounds was assessed first with all usable photographs included in each regional catalogue, representing 1,080 regional sightings (including within-region and between-region resightings) of 949 individual whales from Oceania. From this, 28 cases of movement between (mostly adjacent) regions were documented. Previously undocumented interchange was found between regions of central Oceania and the western South Pacific. No individual was sighted in more than two regions during this six-year period. The documented movement between regions was one-directional, except for one individual sighted first in French Polynesia, then in American Samoa and then back in French Polynesia (each in different years). Only one whale was resighted in more than one region during the same winter season. No directional trend was apparent and movement between regions did not seem to be sex specific. A systematic quality control review of all catalogues was then implemented to calculate standardised indices of within-region return and betweenregion interchange, resulting in a quality controlled catalogue of 776 regional sightings of 659 individuals. The standardised indices confirmed that the probability of between-region interchange was low, relative to within-region return, supporting the assumption of multiple management units or stocks in Oceania. The relative isolation of breeding regions and the movement of individuals across the longitudinal borders of Antarctic management Areas V and VI has important implications for the allocation of historical catches from the Antarctic and therefore, for assessing current levels of recovery for breeding stocks.
\end{abstract}

KEYWORDS: HUMPBACK WHALE; PHOTO-ID; MOVEMENTS; SITE FIDELITY; SOUTH PACIFIC; SOUTHERN HEMISPHERE

\section{INTRODUCTION}

Preliminary comparisons of humpback whales in the South Pacific through photographic catalogues and genetic analyses demonstrate fidelity to local wintering grounds, as well as a low level of migratory interchange among wintering grounds of Oceania, South Pacific (Garrigue et al., 2002; Olavarria et al., 2007; Baker et al., 2006b). In this paper the previously published information on individual movement between wintering grounds of Oceania is extended using photo-identification (photo-id) records collected during six winter seasons (1999-2004) in four primary and five secondary regions. All useable photographs were compared to document movement or interchange between regions. A thorough quality control review of all photographs was then implemented to calculate standardised indices of within and between region return. The fully reconciled (i.e. exhaustively compared) and quality controlled catalogue provided new insight into the migratory fidelity and interchange of individuals among breeding stocks E and F, as recognised by the IWC (Garrigue et al., 2006; IWC, 1998; Olavarria et al., 2007).

\section{MATERIAL AND METHODS}

Dedicated surveys of humpback whales in Oceania were conducted during the austral winters of 1999 to 2004, referred to as 'the synoptic years' in the four primary regions described below: New Caledonia, Tonga, the Cook Islands and French Polynesia (Fig. 1). Although photo-id records are available from previous years for most regions, comparisons described in this paper were restricted to these synoptic survey years. Surveys were conducted in only one or two seasons during the synoptic years in other adjacent regions: Vanuatu; Fiji; Samoa; Niue; and American Samoa, where surveys began in 2003 (Fig. 1).

\section{Primary study sites}

New Caledonia

The Exclusive Economic Zone (EEZ) waters of New Caledonia encompass over $1,450,000 \mathrm{~km}^{2}$ between $18^{\circ}$ and $23^{\circ} \mathrm{S}$ and between $158^{\circ}$ and $172^{\circ} \mathrm{E}$. Some whaling is known to have occurred in the Loyalty Islands of this region, although most of the effort was concentrated in the Chesterfield area (Townsend, 1935). Humpback whale

* ${ }^{1}$ Opération Cétacés, BP 12827, 98802 Nouméa, New Caledonia.

${ }^{2}$ School of Biological Sciences, University of Auckland, Private Bag 92019, Auckland, New Zealand.

${ }^{3}$ Marine Mammal Research, BP698 98728, Maharepa, Moorea, French Polynesia.

${ }^{4}$ Cook Islands Whale Research, Takuvaine Valley, PO Box 3069, Avarua, Rarotonga, The Cook Islands.

${ }^{5}$ Alaska Fisheries Science Center, National Marine Mammal Laboratory, 7600 Sand Point Way NE, Seattle, WA 98115, USA.

${ }^{6}$ Department of Conservation, PO Box 5086, Wellington, New Zealand.

${ }^{7}$ Southern Cross University Whale Research Centre, Southern Cross University, PO Box 157, Lismore, NSW 2480, Australia.

${ }^{8}$ Blue Planet Marine, PO Box 5535, Kingston, ACT 2604, Australia.

${ }^{9}$ Hawaiian Islands Humpback Whale National Marine Sanctuary, Honolulu, Hawaii 96812, USA.

${ }^{10}$ Provincetown Center for Coastal Studies, 5 Holway Avenue, Provincetown 02657, USA.

${ }^{11}$ Marine Mammal Institute, Oregon State University, 2030 SE Marine Science Dr, Newport, OR 97365, USA. 


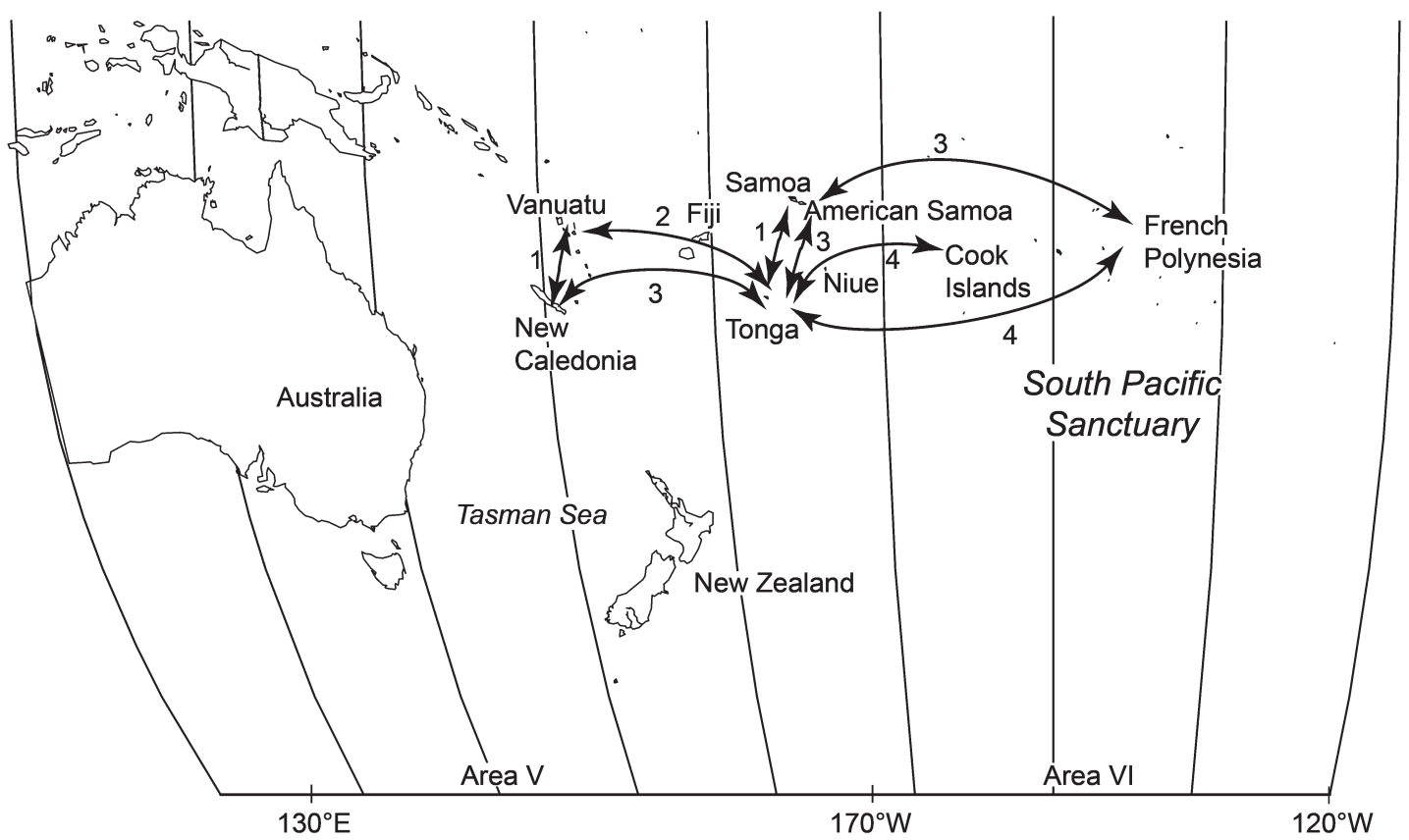

Fig. 1. Location of primary and secondary study regions for photo-identification of humpback whales in Oceania (South Pacific).

photo-id surveys were conducted opportunistically beginning in 1991 (Garrigue and Gill, 1994) and systematically for two to three months each austral winter from 1995 onwards (Garrigue et al., 2001). The present study site covers approximately $1,000 \mathrm{~km}^{2}$ and is located in the southern lagoon off the main island, which is thought to be the primary area of humpback whale density.

\section{Tonga}

The Tongan archipelago is a series of volcanic islands and coral atolls extending $800 \mathrm{~km}$ from Ata in the south to Niuafo'ou in the north with an EEZ of approximately $700,000 \mathrm{~km}^{2}$. The primary areas of humpback whale density are thought to be the three major island groups; Tongatapu in the south; the Ha'apai group in the middle; and the Vava'u group in the north. Vessel-based surveys and the collection of individual identification photographs were initiated in 1991 (Abernethy et al., 1992) and continued in most years prior to the synoptic period of 1999-2004. Each of the three main island groups has been surveyed in at least one year but most of the field effort from 1999 to 2004 was concentrated around Vava'u. The majority of fieldwork has been conducted in August and early September, although work in some years included late July and early October.

\section{Cook Islands}

The Cook Islands are a group of islands and atolls scattered over approximately $2,000,000 \mathrm{~km}^{2}$ of the southwestern South Pacific. Surveys for humpback whales in the southern Cook Islands began with an exploratory three week project in 1998 and continued with a four-month field effort each winter from 1999 until 2004 (Hauser et al., 2000). To date the survey has been focused on three locations: (1) Palmerston Atoll, a small atoll lying at $18^{\circ} 04^{\prime} \mathrm{S}, 163^{\circ} 10^{\prime} \mathrm{W}$ on the north western margin of the Southern Cook group; (2) Aitutaki, an island located at $18^{\circ} 55^{\prime} \mathrm{S}, 159^{\circ} 47^{\prime} \mathrm{W}$, roughly $300 \mathrm{~km}$ east of Palmerston; and (3) Rarotonga, an island located at $21^{\circ} 14^{\prime} \mathrm{S}, \quad 159^{\circ} 48^{\prime} \mathrm{W}$, roughly $430 \mathrm{~km}$ southeast of Palmerston. Other brief surveys included the islands of Atiu and Mangaia.

\section{French Polynesia}

French Polynesia comprises five archipelagos (the Marquesas, the Tuamotu atolls, the Gambiers, the Society Islands and the Australs) in the central South Pacific Ocean. Sightings of humpback whales in French Polynesia's waters have been noted since 1988 (Poole and Darling, 1999). The primary study area for fieldwork has encompassed the nearshore waters of the high island of Mo'orea in the Society Islands, lying at $17^{\circ} 30^{\prime} \mathrm{S}$ and $149^{\circ} 50^{\prime} \mathrm{W}, 18 \mathrm{~km}$ northwest of Tahiti. Observational surveys of humpback whales in the nearshore waters of Mo'orea began in 1991. Additional shore- and boat-based observations of humpback whales began in 1999 at Rurutu in the Austral Islands. From 1999 to 2004 most of the field effort was concentrated around Mo'orea and Rurutu (Poole, 2002).

\section{Individual identification and matching process}

Humpback whales were individually identified in each region from photographs of the unique markings on the ventral surface of their tail flukes, i.e. photo-id (Katona et al., 1979). All photographs considered 'usable' (e.g. potentially matchable) by the regional coordinators were first matched within regions, leading to 'reconciled' regional catalogues of all annual sightings within regions and between years.

These regional catalogues of unique individuals for the nine regions were then matched by exhaustive pair-wise comparisons during annual meetings of the South Pacific Whale Research Consortium (SPWRC). The number of between-region (within- and between-year) resightings were recorded. All between-region resightings were confirmed by three independent matchers. This initial comparison resulted in a fully reconciled, non-quality controlled catalogue, including all within-region (between-year) resightings and all between region (within- and between-year) resightings. Although it was assumed that usable photographs of marginal quality would be more difficult to match, no evidence of false matches (e.g. mismatches, Perry et al., 1990) was found in the subsequent quality control review of all catalogues (see below). 
The results of this initial non-quality controlled comparison were reported to the IWC workshop on the Comprehensive Assessment of Southern Hemisphere humpback whales held in Hobart in April 2006 (SPWRC et al., 2006). Subsequent to this workshop, members of the SPWRC agreed to review all photographs following a set of quality control standards in order to minimise bias (i.e. missed matches, defined as a match that is not recognised because of poor quality photographs) in calculating return and interchange rates, as well as for subsequent estimates of abundance.

\section{Quality control review}

All images of the fully reconciled, non-quality controlled catalogue of Oceania were reviewed according to a standard set of quality control criteria originally developed for the SPLASH programme in the North Pacific (Calambokidis et al., 2008). This is a scoring system based on objective quality measures of the images, irrespective of distinctiveness of the fluke. It consists of five quality criteria, each of which is scored from the highest (1) to the lowest (5) quality. These five categories were: (i) proportion of the fluke visible; (ii) fluke angle; (iii) the lateral angle of the photographer; (iv) exposure quality; and (v) contrast quality, as described in Calambokidis et al. (2001). An image that received a score of four or five in any of the five quality categories was judged to be of insufficient quality for a standardised comparison of within-region return rates and between-region resight rates. As recommended by Friday (1997) and Friday et al. (2000), the quality control review of all catalogues was undertaken by a single researcher familiar with cetacean photo-id (RC) in order to ensure consistency. Exhaustive matching of all regional catalogues using the quality control scores resulted in a single 'quality controlled, fully reconciled' catalogue for Oceania.

\section{Return and interchange indices}

The within-region return index and the between-region interchange index were calculated to evaluate the relative magnitude of migratory interchange (Garrigue et al., 2002) following Baker et al. (1986) and Calambokidis et al. (2001).

The return index of within-region annual resightings was calculated as:

$$
\mathrm{Rij}=\mathrm{Mi}, \mathrm{j} /(\mathrm{Ai} \times \mathrm{Bi}) \times 1,000
$$

where

$\mathrm{Ai}=$ number of whales marked in all the years before 2004;

$\mathrm{Bi}=$ number of whales identified in 2004; and
$\mathrm{Mi}, \mathrm{j}=$ number of whales marked in any previous years and resighted in 2004.

An interchange index of between-region resights was calculated as:

$$
\mathrm{Rij}=\mathrm{Mi}, \mathrm{j} /(\mathrm{A} 1 \times \mathrm{B} 2) \times 1,000
$$

where

$\mathrm{A} 1=$ number of whales identified in region $\mathrm{A}$;

$\mathrm{B} 2=$ number of whales identified in region $\mathrm{B}$; and

$\mathrm{Mi}, \mathrm{j}=$ number of whales identified in both regions.

The indices were considered to be zero when there were no whales were sighted within or between regions (i.e. when $\mathrm{Mi}, \mathrm{j}=0)$.

Indices were calculated for the synoptic period 1999-2004 using all photographs contained in the fully reconciled, quality controlled catalogue of Oceania.

\section{RESULTS}

\section{Between-region resightings}

The fully reconciled, non-quality controlled catalogue of Oceania represented 1,080 regional sightings (including within-region, between-year resightings) of 949 individually identified humpback whales in Oceania. This comparison provided 28 matches documenting movements between regions (Tables 1 and 2), of which 22 involved movement from or to Tonga, a central Oceania region represented by the largest catalogue. Of the 28 total, 9 corresponded to individuals observed in one of the four primary regions (mostly Tonga) and resighted in one of the secondary study regions (Vanuatu 3, Samoa 1, American Samoa 6, Niue 1). The other matches $(n=17)$ were between Tonga and New Caledonia, the Cook Islands or French Polynesia. One individual was resighted during the same year in two regions (ID: TGVA9989-CIMn081999, Tonga and the Cook Islands). The majority of observed movements were uni-directional with one exception: an individual was sighted in French Polynesia, then in American Samoa and then back in French Polynesia (FP0003/AS012; Table 2). No individual was sighted in more than two regions during the six years of synoptic surveys.

\section{Quality control review}

Following the quality control review of the regional catalogues, $34 \%$ of the submitted photographs were judged to be of insufficient quality for standardised comparisons and were excluded from calculation of resighting rates (Table 3 ). The number of individual whales photographically identified

Table 1

Movement by individual whales between regions before quality control (below diagonal) and after quality control (above

\begin{tabular}{|c|c|c|c|c|c|c|c|c|c|}
\hline Regions & $\mathrm{NC}$ & VT & FI & SA & $\mathrm{TG}$ & NI & $\mathrm{CI}$ & FP & AS \\
\hline New Caledonia (NC) & & 1 & 0 & 0 & 3 & 0 & 0 & 0 & 0 \\
\hline Vanuatu (VT) & 1 & & 0 & 0 & 2 & 0 & 0 & 0 & 0 \\
\hline Fiji (FI) & 0 & 0 & & 0 & 0 & 0 & 0 & 0 & 0 \\
\hline Samoa (SA) & 0 & 0 & 0 & & 1 & 0 & 0 & 0 & 0 \\
\hline Tonga (TG) & 4 & 2 & 0 & 1 & & 0 & 4 & 4 & 2 \\
\hline Niue (NI) & 0 & 0 & 0 & 0 & 0 & & 0 & 0 & 0 \\
\hline Cook Island (CI) & 0 & 0 & 0 & 0 & 7 & 1 & & 0 & 0 \\
\hline French Polynesia (FP) & 0 & 0 & 0 & 0 & 6 & 0 & 0 & & 3 \\
\hline American Samoa (AS) & 0 & 0 & 0 & 0 & 2 & 0 & 1 & 3 & \\
\hline
\end{tabular}
diagonal, in italics). 
Table 2

Summary of movement of individual humpback whales between the regions of Oceania based on all usable (non-quality controlled) fluke ID photographs (underline indicates photographs that did not pass quality control ranking). Direction: East (E), West (W) or Northeast (NE).

\begin{tabular}{|c|c|c|c|c|}
\hline ID & First/third region/year & Direction & Second region/year & Sex \\
\hline & New Caledonia & & Vanuatu & \\
\hline \multirow[t]{2}{*}{ HNC102/VT001 } & 2001 & $\mathrm{E}$ & 2003 & Female \\
\hline & New Caledonia & & Tonga & \\
\hline HNC209/TGVA0363 & 2001 & E & 2003 & Male \\
\hline \multirow[t]{2}{*}{ HNC193/TGVA0248 } & 2000 & E & 2002 & Male \\
\hline & Tonga & & New Caledonia & \\
\hline TGVA9946/HNC217 & 1999 & W & 2001 & Male \\
\hline \multirow[t]{2}{*}{ TGVA9977/HNC239 } & 1999 & W & 2001 & Male \\
\hline & Tonga & & Vanuatu & \\
\hline TGVA0208/VT004 & 2002 & W & 2003 & Unknown \\
\hline \multirow[t]{2}{*}{ TGHA0003/VT002 } & 2000 & W & 2003 & Male \\
\hline & Tonga & & American Samoa & \\
\hline TGVA9984/AS062 & 1999 & $\mathrm{NE}$ & 2004 & Unknown \\
\hline \multirow{2}{*}{ TGVA9905/AS049 } & 1999 & $\mathrm{NE}$ & 2004 & Unknown \\
\hline & Tonga & & Samoa & \\
\hline \multirow[t]{2}{*}{ TGVA0410/SA01-002 } & 2001 & $\mathrm{NE}$ & 2004 & Unknown \\
\hline & Tonga & & Cook Islands & \\
\hline TGVA0082/CIMn082802 & 2000 & E & 2002 & Female \\
\hline TGVA9952/CIMn83103 & 1999/2001 & E & 2003 & Unknown \\
\hline \multirow[t]{2}{*}{ TGVA9920/CIMn092102 } & 1999 & $\mathrm{E}$ & 2002 & Unknown \\
\hline & Cook Islands & & Tonga & \\
\hline CIMn081999/TGVA9989 & 1999 & W & 1999 & Male \\
\hline CIMn080700/TGVA0226 & 2000 & W & 2002 & Male \\
\hline CIMn082200/TGVA0146 & 2000 & $\mathrm{~W}$ & 2001 & Female \\
\hline \multirow[t]{2}{*}{ CIMn100900/TGVA0413 } & 2000 & W & 2004 & Unknown \\
\hline & Cook Islands & & Niue & \\
\hline \multirow[t]{2}{*}{$\underline{\text { CIMn080700/Niue0102 }}$} & 2000 & W & 2001 & Unknown \\
\hline & Cook Islands & & American Samoa & \\
\hline \multirow[t]{2}{*}{$\mathrm{CIMn} 081903 / \underline{\mathrm{AS} 036}$} & 2003 & E & 2004 & Unknown \\
\hline & Tonga & & French Polynesia & \\
\hline TGVA0064/FP0452 & 2000 & E & 2004 & Unknown \\
\hline TGVA9938/FP0453 & 1999 & $\mathrm{E}$ & 2004 & Unknown \\
\hline TGVA9968/FP0464 & 1999 & $\mathrm{E}$ & 2004 & Unknown \\
\hline TGVA0170/FP0463 & 2001 & E & 2004 & Unknown \\
\hline \multirow[t]{2}{*}{ TGVA0057/FP0337 } & 2000 & $\mathrm{E}$ & $2003 / 2004$ & Unknown \\
\hline & French Polynesia & & American Samoa & \\
\hline FP0201/AS005 & 2002 & W & 2003 & Unknown \\
\hline FP0003/AS012 & $2000 / 2004$ & $\mathrm{~W} / \mathrm{E}$ & 2003 & Unknown \\
\hline \multirow[t]{2}{*}{ FP0316/AS059 } & 2003 & W & 2004 & Unknown \\
\hline & French Polynesia & & Tonga & \\
\hline FP200212/TGVA0402 & $2002^{\circ}$ & W & 2004 & Unknown \\
\hline
\end{tabular}

in each region after the quality control, and the number of individual whales resighted within region are presented in Table 3 (South Pacific Whale Research Consortium, 2001; $2002 ; 2003 ; 2004 ; 2005)$. The comparison of the fully reconciled, quality controlled catalogue of Oceania represented 776 regional sightings of 659 individual humpback whales in Oceania (Table 3). Of the 28 cases of between region movement documented in the non-quality controlled catalogue, 8 involved a photograph judged to be of unacceptable quality for calculating the standardised resighting indices (Table 1, upper diagonal). In each case, only one of the two photos was rejected from these matches (5 for Tonga, 2 for Cook Islands and 1 for American Samoa). Despite the lower quality of these photographs, there was no uncertainty in matches to the higher quality photographs and, thus, no uncertainty in the documentation of these individual movements.

\section{Within-region resightings and resighting indices}

In the quality-controlled catalogue of 776 regional sightings, 78 resightings were found between years within three of the primary regions. Between 1999 and 2004 a total of 33 individuals were resighted in New Caledonia representing $21 \%$ of the individually identified humpback whales during the same period (Table 3). In Tonga a total of $25(9 \%)$ individual whales were resighted within the region. In French Polynesia, a total of $20(13 \%)$ individual whales were resighted within the region (Table 3 ). All but one individual were resighted only once in Tonga and French Polynesia. More than one-third of the resighted individuals were observed more than once in New Caledonia with 11 individuals sighted three times and one sighted in four occasions. No individual was resighted between years in the Cook Islands (Table 3). These results lead to high withinregion return indices for all primary regions except for Cook Islands (Table 4). No individual was resighted within the secondary regions in which sampling took place for more than one year (e.g. Samoa and American Samoa, Table 3).

Comparisons of the within- and between-region resight indices confirmed the previous reports of fidelity to individual breeding grounds (Table 4; Garrigue et al., 2001). 
Table 3

Summary of individual identification photographs of humpback whales by regions of Oceania between 1999 and 2004, with the number of sightings by region and number of individual whales resighted within regions.

\begin{tabular}{|c|c|c|c|c|c|}
\hline Regions & $\begin{array}{l}\text { Years of } \\
\text { sampling } \\
\text { effort }\end{array}$ & $\begin{array}{l}\text { Number of } \\
\text { usable ID } \\
\text { photos }\end{array}$ & $\begin{array}{l}\text { Number of ID } \\
\text { photos after } \\
\text { quality control }\end{array}$ & $\begin{array}{l}\text { Number of } \\
\text { annual } \\
\text { sightings }\end{array}$ & $\begin{array}{c}\text { Number of individual } \\
\text { whales resighted between } \\
\text { years, within regions }\end{array}$ \\
\hline New Caledonia (NC) & 1999-2004 & 185 & 160 & 206 & 33 \\
\hline Vanuatu (VT) & 2003 & 6 & 6 & 6 & - \\
\hline Fiji (FI) & $2002-03$ & 2 & 2 & 2 & 0 \\
\hline Samoa (SA) & 2001,2003 & 2 & 1 & 1 & 0 \\
\hline Tonga (TG) & 1999-2004 & 422 & 282 & 312 & 25 \\
\hline Cook Island (CI) & 1999-2004 & 90 & 36 & 36 & 0 \\
\hline French Polynesia (FP) & 1999-2004 & 230 & 159 & 180 & 20 \\
\hline American Samoa (AS) & 2003-04 & 39 & 31 & 31 & 0 \\
\hline Unreconciled, non-quality controlled catalogue of Oceania & 1999-2004 & 949 & - & 776 & - \\
\hline Unreconciled, quality controlled catalogue of Oceania & 1999-2004 & - & 679 & 776 & 78 \\
\hline Total individuals in reconciled, quality controlled catalogue & 1999-2004 & - & 659 & - & - \\
\hline
\end{tabular}

Only the interchange between Tonga and the Cook Islands showed a resight index of the same order of magnitude as the return index calculated for Tonga, suggesting a close migratory connection. This connection was recently highlighted using satellite telemetry (Hauser et al., 2010).

\section{DISCUSSION}

The first information on movements of individual humpback whales in the South Pacific came from Discovery marking (Dawbin, 1959; 1964). However, given the pattern of marking and recovery, no exchanges between the islands of Oceania were revealed by this method. The first, and only previous records have come from photo-id studies initiated in the early 1990s (Abernethy et al., 1992; Garrigue et al., 2001; Hauser et al., 2000; Poole, 2002). The present study confirms that the majority of inter-annual resightings of humpback whales in Oceania occurred within regions $(80 \%$ of the matches for the quality-controlled catalogue). This is an order of magnitude greater that the between-region interchange, with the exception of Tonga and the Cook Islands (Table 4) confirming both site fidelity and limited demographic exchange between breeding grounds (Garrigue et al., 2002). The rate of resightings varied within the four primary regions presumably due to local abundance. The highest percentage of within-region resightings was measured in New Caledonia $(21 \%)$ and the lowest in the Cook Islands, where none were observed in the course of this six-year study. No within-region resighting was reported from the secondary study regions where numbers appear low and sample sizes were small. Although surveying of all regions of known historical abundance (e.g. Fiji and Samoa) has been attempted, it is also probable that humpback whales inhabit other regions of Oceania where sampling has not yet been conducted.

\section{Table 4}

Within-region return index (in italics) and between-region interchange index of humpback whales calculated from quality control catalogues for the four primary breeding grounds of Oceania.

\begin{tabular}{lcccc}
\hline Regions & NC & TG & CI & FP \\
\hline New Caledonia (NC) & 4.28 & 0.07 & 0.00 & 0.00 \\
Tonga (TG) & & 0.94 & 0.39 & 0.09 \\
Cook Islands (CI) & & & 0.00 & 0.00 \\
French Polynesia (FP) & & & & 3.42 \\
\hline
\end{tabular}

The between-region resightings reported here contributed to previously reported observations of connections (see Introduction) and revealed several new connections, especially in central Polynesia. Tonga showed interchange with Samoa, American Samoa, the Cook Islands and French Polynesia. Similarly, French Polynesia showed interchange with American Samoa. In the western South Pacific exchange was documented between Vanuatu and both New Caledonia and Tonga. No individual whale was sighted in more than two regions and all observed movement was limited to adjacent regions. Most of the whales resighted between regions have been identified only once in each region, suggesting that these movements are transient or exploratory (Madon, 2010) rather than permanent dispersal events (see below).

Most (70\%) of the between-region resightings were in the central South Pacific and involved Tonga, the Cook Islands, French Polynesia, American Samoa and Samoa. The others $(30 \%)$ were observed in the western South Pacific and involved New Caledonia, Vanuatu and Tonga. No movements were documented between the central and western South Pacific during the six years of this study. However, photo-id records outside of the synoptic years and recent genotyping comparisons (South Pacific Whale Research Consortium, 2008) revealed the movement of one whale from New Caledonia (1998) to Tonga (2001) and then on to French Polynesia (2004) and one whale from New Caledonia (2000) to the Cook Islands (2007). Thus, it is clear that, although infrequent, there is movement on an oceanwide scale over years. No directional trends were found in the movements. Half of the documented movement was in a westerly direction and half in an easterly direction. Sex information was available for eight of the whales that moved between regions; six males and two females. Even though the sample size is small, this suggests that movement is not sex-specific (although it might be sexed biased).

Overall, the level of movement of individuals between adjacent sites within Oceania, and the apparent transient nature of this interchange, is consistent with the significant levels of differentiation observed in mtDNA from these regions (Olavarria et al., 2007). Assuming Wright's Island model of gene flow and a generation time of 18 years, Olavarria et al. (2007) used the estimated $F_{\mathrm{ST}}$ from mtDNA haplotypes to calculate an exchange rate of about one female per year among the breeding grounds of Oceania. These low levels of maternal gene flow and the relatively low rates of between-region interchange (relative to within-region return) 
from the photo-id comparisons, suggest that populations of humpback whales wintering near or in New Caledonia, Tonga and French Polynesia are independent from each other (and from breeding grounds to the east and west), on a demographic time scale, and should be recognised as individual breeding stocks. This does not seem to be the case for the Cook Islands, which shows less evidence of isolation from neighbouring regions. Consequently, a comprehensive assessment of South Pacific stocks should, ideally, attempt to consider each of these primary breeding grounds independently in regards to current abundance, past catches and rates of increase. However, we recognise that such a fine-scale assessment might not be possible in the near term, given regional samples sizes available for estimating abundance and the uncertainty of allocating historical Antarctic catches. Other approaches should be explored, including aggregating regional catalogues for estimating abundance (Baker et al., 2006) and Bayesian modelling of catch allocation to two stocks, eastern Australia and Oceania (Jackson et al., 2008). In the longer term, a greater sampling effort for photo-identification and individual genotying (Steel et al., 2008) is needed to better estimate abundance and interchange between breeding grounds and describing connections between Oceania and Antarctic feeding areas.

\section{ACKNOWLEDGEMENTS}

This large-scale comparison was made possible through the generous collaboration of members and affiliates of the South Pacific Whale Research Consortium (SPWRC), with the support of the International Fund for Animal Welfare (IFAW). For support in French Polynesia we thank West Marine Products, M. Poliza and the Starship Millennium Voyage, Office des Postes et Télécommunications, Sin Tung Hing Marine, Mercury Outboards, West Coast Whales Research Foundation, the Foundation Naturalia et Biologia, Hardy Jones-Julia Whitty Productions, the Raie Manta Club, Cine Marine, Eco-media Productions, Canal+, the BBC and the Conservation Action Fund. In the Cook Islands, we thank the Cook Island Government, T. Pryor, the people of Rarotonga, Aitutaki and Palmerston, J. Daeschler, H. Hauser and D. and J. Macrae. Surveys of humpback whales in New Caledonia were made possible by contributions the Provinces Sud, North and Isles, Inco S.A. We thank Rémi Dodemont, Jacqui Greaves, Dominique Breitenstein, Veronique Ducreux, Magaly Chambellant and all the volunteers that helped in the field. Field research was carried out by 'Opération Cétacés' under a permit issued by the Province Sud. Research in the Kingdom of Tonga was conducted under scientific permit from the Tongan Ministry of Fisheries and His Majesty, the King of Tonga, with funding from the International Whaling Commission, University of Auckland Research Council, Whale and Dolphin Conservation Society, South Pacific Regional Environment Program (SPREP), Whale and Dolphin Adoption Project, Pacific Development Trust of New Zealand and Cetacean Society International. We thank B. Abernethy, N. Patenaude, S. Childerhouse, N. Gibbs, T. O'Callaghan, C. Nichols, K. McLeod, A., N. and K. Baker, B. Todd, R. Barrel, the sailing vessel Nai'a and The Moorings-Tonga for field support. We acknowledge Natural Heritage Trust (Australia) for funding the survey in Vanuatu and Fiji proposed in 2003. We also wish to acknowledge the advice and assistance from Job Opu (Marine Mammals SPREP Officer) and Robyn McCulloch from Environment
Australia (now DEWHA). For research in American Samoa, we thank the Government of American Samoa Division of Marine and Wildlife Resources, the Fagatele Bay National Marine Sanctuary and the National Park of American Samoa. Research activities were conducted under the authorization of NOAA fisheries permit 774-1437 and a scientific permit issued by the government of American Samoa. Finally, we thank the two anonymous reviewers for their comments that improved this paper.

\section{REFERENCES}

Abernethy, R.B., Baker, C.S. and Cawthorn, M.W. 1992. Abundance and genetic identity of humpback whales (Megaptera novaeangliae) in the southwest Pacific. Paper SC/44/O20 presented to the IWC Scientific Committee, June 1992 (unpublished). 46pp. [Paper available from the Office of this Journal].

Baker, C.S., Garrigue, C., Constantine, R., Madon, B., Poole, M., Hauser, N., Clapham, P., Donoghue, M., Russell, K., O’Callahan, T., Paton, D. and Mattila, D. 2006a. Abundance of humpback whales in Oceania (South Pacific), 1999 to 2004. Paper SC/A06/HW51 presented to the IWC Workshop on Comprehensive Assessment of Southern Hemisphere Humpback Whales, Hobart, Tasmania, 3-7 April 2006 (unpublished). 10pp. [Paper available from the Office of this Journal].

Baker, C.S., Garrigue, C., Constantine, R., Poole, M., Hauser, N., Clapham, P., Donoghue, M., Russell, K., Paton, D. and Mattila, D. 2006 b. Interchange of humpback whales in Oceania (South Pacific), 1999 to 2004. Paper SC/A06/HW55 presented to the IWC Workshop on Comprehensive Assessment of Southern Hemisphere Humpback Whales, Hobart, Tasmania, 3-7 April 2006 (unpublished). 10pp. [Paper available from the Office of this Journal].

Baker, C.S., Herman, L.M., Perry, A., Lawton, W.S., Straley, J.M., Wolman, A.A., Kaufman, G.D., Winn, H.E., Hall, J.D., Reinke, J.M. and Ostman, J. 1986. Migratory movement and population structure of humpback whales, Megaptera novaeangliae, in the central and eastern North Pacific. Mar. Ecol. Prog. Ser. 31: 105-19.

Calambokidis, J., Falcone, E.A., Quinn, T.J., Burdin, A.M., Clapham, P.J., Ford, J.K.B., Gabriele, C.M., LeDuc, R., Mattila, D., Rojas-Bracho, L., Straley, J.M., Taylor, B.L., Urban R, J., Weller, D., Witteveen, B.H., Yamaguchi, M., Bendlin, A., Camacho, D., Flynn, K., Havron, A., Huggins, J. and Maloney, N. 2008. SPLASH: Structure of Populations, Levels of Abundance and Status of Humpback Whales in the North Pacific. Final report for Contract AB133F-03-RP-00078, US Department of Commerce Western Administrative Center, Seattle, Washington. [Available at http://www.cascadiaresearch.org/SPLASH/SPLASHcontract-report-May08.pdf].

Calambokidis, J., Steiger, G.H., Straley, J., Herman, L.M., Cerchio, S., Salden, D., Urbán R, J., Jacobsen, J.K., von Zeigesar, O., Balcomb, K.C., Gabriele, C.M., Dahlheim, M.E., Uchida, S., Ellis, G., Miyamura, Y., Ladrón de Guevara P, P., Yamaguchi, M., Sato, F., Mizroch, S.A., Schlender, L., Rasmussen, K., Barlow, J. and Quinn II, T.J. 2001. Movements and population structure of humpback whales in the North Pacific. Mar. Mammal Sci. 17(4): 769-94.

Dawbin, W.H. 1959. New Zealand and South Pacific whale marking and recoveries to the end of 1958. Norsk Hvalfangsttid. 48(5): 213-38.

Dawbin, W.H. 1964. Movements of humpback whales marked in the southwest Pacific Ocean 1952 to 1962. Norsk Hvalfangsttid. 53(3): 6878

Friday, N. 1997. Evaluating photographic capture-recapture estimates of abundance of North Atlantic humpback whales, Graduate School of Oceanography, University of Rhode Island. 173pp.

Friday, N., Smith, T., Stevick, P. and Allen, J. 2000. Measurement of photographic quality and whale distinctiveness for the photographic identification of humpback whales. Mar. Mammal Sci. 16(2): 355-74.

Garrigue, C., Aguayo, A., Amante-Helwig, V.L.U., Baker, C.S., Caballero, P., Clapham, P., Constantine, R., Denkinger, J., Donoghue, M., FlorezGonzalez, L., Greaves, J., Hauser, N., Olavarria, C., Pairoa, C., Peckham, H. and Poole, M. 2002. Movements of humpback whales in Oceania, South Pacific. J. Cetacean Res. Manage. 4(3): 255-60.

Garrigue, C. and Gill, P.C. 1994. Observations of humpback whales, Megaptera novaeangliae in New Caledonian waters during 1991-1993. Biol. Conserv. 70(3): 211-18.

Garrigue, C., Greaves, J. and Chambellant, M. 2001. Characteristics of the New Caledonian humpback whale population. Mem. Queensl. Mus. 47(2): 539-46.

Garrigue, C., Olavarria, C., Baker, C.S., Steel, D., Dodemont, R., Constantine, R. and Russell, K. 2006. Demographic and genetic isolation of New Caledonia (E2) and Tonga (E3) breeding stocks. Paper 
SC/A06/HW19 presented to the IWC Workshop on Comprehensive Assessment of Southern Hemisphere Humpback Whales, Hobart, Tasmania, 3-7 April 2006 (unpublished). 10pp. [Paper available from the Office of this Journal].

Hauser, N., Peckham, H. and Clapham, P. 2000. Humpback whales in the Southern Cook Islands, South Pacific. J. Cetacean Res. Manage. 2(3): 159-64.

Hauser, N., Zerbini, A.N., Geyer, Y., Heide-Jorgensen, M.P. and Clapham, P.J. 2010. Movements of satellite-monitored humpback whales, Megaptera novaeangliae, from the Cook Islands. Mar. Mammal Sci. 26(3): 679-85.

International Whaling Commission. 1998. Report of the Scientific Committee. Annex G. Report of the sub-committee on Comprehensive Assessment of Southern Hemisphere humpback whales. Rep. int. Whal. Commn 48:170-82.

Jackson, J., Zerbini, A., Clapham, P., Constantine, R., Garrigue, C., Hauser, N., Poole, M. and Baker, C.S. 2008. Progress on a two-stock catch allocation model for reconstructing population histories of east Australia and Oceania. Paper SC/60/SH14 presented to the IWC Scientific Committee, June 2008, Santiago, Chile (unpublished). 12pp. [Paper available from the Office of this Journal].

Katona, S., Baxter, B., Brazier, O., Kraus, S., Perkins, J. and Whitehead, H. 1979. Identification of humpback whales by fluke photographs. pp.3344. In: Winn, H.E. and Olla, B.L. (eds). Behaviour of marine mammals, Vol. 3: Cetaceans. Plenum Press, New York and London. i-xix+438pp.

Madon, B. 2010. An extension of the Jolly-Seber model combining of two sources of mark-recapture data. $\mathrm{PhD}$ thesis, University of Auckland, New Zealand.

Olavarria, C., Baker, C.S., Garrigue, C., Poole, M., Hauser, N., Caballero, S., Florez-Gonzalez, L., Brasseur, M., Bannister, J., Capella, J., Clapham, P., Dodemont, R., Donoghue, M., Jenner, C., Jenner, M.N., Moro, D., Oremus, M., Paton, D. and Russell, K. 2007. Population structure of South Pacific humpback whales and the origin of the eastern Polynesian breeding grounds. Mar. Ecol. Prog. Ser. 330: 257-68.

Perry, A., Baker, C.S. and Herman, L.M. 1990. Population characteristics of individually identified humpback whales in the central and eastern North Pacific: a summary and critique. Rep. int. Whal. Commn (special issue) 12: 307-17.

Poole, M.M. 2002. Occurrence of humpback whale (Megaptera novaeangliae) in French Polynesia 1988-2001. Paper SC/54/H14 presented to the IWC Scientific Committee, April 2002, Shimonoseki, Japan (unpublished). 12pp. [Paper available from the Office of this Journal].

Poole, M.M. and Darling, J. 1999. Occurrence of humpback whales (Megaptera novaeanglia) in French Polynesia. Proceedings of the
Thirteenth Biennial Conference on the Biology of Marine Mammals, 27 November to 4 December 1999, Maui, Hawaii, USA (Abstract). p. 150 .

South Pacific Whale Research Consortium. 2001. Report of the Annual Meeting of the South Pacific Whale Research Consortium, 9-12 April 2001, Auckland, New Zealand. 14. 14pp. [Available from: South Pacific Whale Research Consortium, PO Box 3069, Avarua, Rarotonga, Cook Islands].

South Pacific Whale Research Consortium. 2002. Report of the Annual Meeting of the South Pacific Whale Research Consortium, 24-28 February 2002, Auckland, New Zealand. Paper SC/54/O14 presented to the IWC Scientific Committee, April 2002, Shimonoseki, Japan (unpublished). 12pp. [Paper available from the Office of this Journal].

South Pacific Whale Research Consortium. 2003. Report of the Annual Meeting of the South Pacific Whale Research Consortium, 13-17 February 2003, Auckland, New Zealand. Paper SC/55/SH2 presented to the IWC Scientific Committee, May 2003, Berlin (unpublished). 11pp. [Paper available from the Office of this Journal].

South Pacific Whale Research Consortium. 2004. Report of the Annual Meeting of the South Pacific Whale Research Consortium, 2-6 April 2004, Byron Bay, NSW, Australia. Paper SC/56/SH7 presented to the IWC Scientific Committee, July 2004, Sorrento, Italy (unpublished). 9pp. [Paper available from the Office of this Journal].

South Pacific Whale Research Consortium. 2005. Report of the Annual Meeting of the South Pacific Whale Research Consortium, Auckland, New Zealand, 11-13 March 2005. Paper SC/57/SH9 presented to the IWC Scientific Committee, June 2005, Ulsan, Korea (unpublished). 11pp. [Paper available from the Office of this Journal].

South Pacific Whale Research Consortium. 2008. Report of the Annual Meeting of the South Pacific Whale Research Consortium Auckland, New Zealand, 5-8 February 2008. Paper SC/60/SH21 presented to the IWC Scientific Committee, June 2008 (unpublished). 15pp. [Available from the Office of the Journal].

Steel, D., Garrigue, C., Poole, M., Hauser, N., Olavarría, C., FlórezGonzález, L., Constantine, R., Caballero, S., Thiele, D., Paton, D., Clapham, P., Donoghue, M. and Baker, C.S. 2008. Migratory connections between humpback whales from South Pacific breeding grounds and Antarctic feeding areas based on genotye matching. Paper SC/60/SH13 presented to the IWC Scientific Committee, June 2008, Santiago, Chile (unpublished). 9pp. [Paper available from the Office of this Journal].

Townsend, C.H. 1935. The distribution of certain whales as shown by logbook records of American whaleships. Zoologica (NY) 19(1-2): 1$50+6$ maps. 